臨床肝硬変に続発した乳び腹水の 1 剖検例

特にリンパ管造影所見乱よび腹水中リポ蛋白について

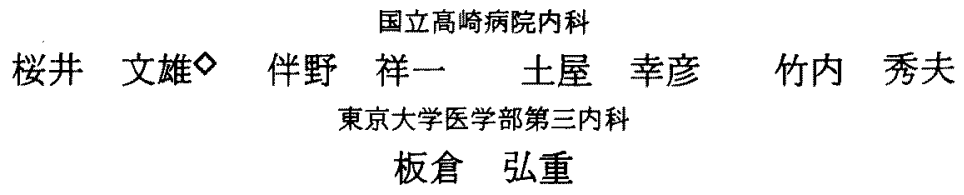

\title{
CHYLOUS ASCITES SECONDARY TO LIVER CIRRHOSIS WITH SPECIAL REFERENCE TO LYMPHANGIOGRAPHY AND LIPOPROTEIN ANALYSIS OF CHYLOUS ASCITES
}

\author{
Humio SaKuRaI, MD, Shoichi Tomono, MD, Yukihiko TsuchIYa, MD \\ and Hideo TAKEUCHI, MD \\ Department of Internal Medicine, Takasaki National Hospital, Takasaki \\ Hiroshige ITAKURA, MD
}

The Third Department of Internal Medicine, Faculty of Medicine

University of Tokyo, Tokyo

\begin{abstract}
概要 肝硬变以外に腫瑒や炎症などの要因なく，乳び腹水を続発した症例を経験したので報告 する．症例は50才の男性で，既往に昭和 30 年肺結核による肺切除原後の輸血後肝炎がある．昭 和56年11月，腹水詝留を主訴として入院した。症状ょよび検査成績より肝硬変の非代償期之診 断し，安静，減塩高蛋白食および利尿薬投与にて腹水は，一時消失したが，入院12週頃より再 眝留し，利尿薬に反応せず，腹水は乳様混濁を呈してきた。腹水中のトリグリセライドは著し く増加し，血清値より高値で、トリグリセライド/コレステロール比は高く，超遠心法を用いた 蛋白分析では比重1.006以下の分画が著增していた。リンハ管造影では，乳び槽近くでの不完全 閉塞を思わせる所見が得られたが，剖検ではリンパ路の異常は認められなからた，乳び腹水中 の比重1.006以下のリポ蛋白分画のpolyacrylamide gel electrophoresisによるアポリポ蛋白分

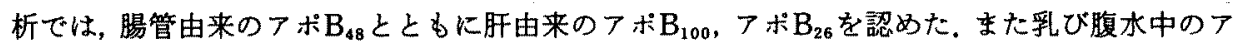
ポA定量では，アポAI $10.6 \mathrm{mg} / \mathrm{dl}$, アポAII $1.3 \mathrm{mg} / \mathrm{dl} の$ 值を得, アポAI/AII比は正常血清と比 ベ上昇していた，われわれの知る限り，本症例は肝硬変に続発した乳び腹水のアボリボ蛋白分 析を行なつた最初の報告例である。
\end{abstract}

\section{I. 緒}

乳び腹水の発生原因の一つとして肝硬变がある がそその詳細な報告例は少ない，今回，著者らは， 肝硬変に続発した乳び腹水例を経験し，そのリン ハ管造影およびリポ蛋白分析にて興味ある知見を 得たので, 肝硬変症に淤る乳び腹水の発生機序 に関し若干の考察を加克て報告する。

[昭和59年 3 月 13 日受稿]

\section{II. 症例}

\section{患者： 50 才，男性.}

主訴：腹水詝留

家族歴：特記すべきものはない．

既往歴：（1）昭和28年 肺結核 (右肺). (2) 昭和 30 年 1 月 右肺上葉切除術. 輸血 $1200 \mathrm{ml}$. (3) 同年 6 月 輸血後肝炎, (4) 同年 8 月 右胸郭形 成術。嗜癖；ウィスキ-200 300 $\mathrm{ml} /$ 日（30年 間), タバコ 30 本/日（30年間）. 
現病歴：昭和 39 年, 近医にて肝障害を指摘さ れ，酒量をひかえるように指示されたが放圆，以 後数回, 眼球結膜の黄変することがあつたが医院 を受診することなく経過した。昭和56年 8 月頃よ クタ方になると下肢に浮腫が出現するようにな り，10月16日左第 5 趾骨折の為，自宅静養するよ らになつた。休養中かえつて酒量が増え，11月に 入ると急に腹水詝留が出現したため，11月29日当 科入院となつた。

入院時現症：身長 $172 \mathrm{~cm}$, 体重 $83.5 \mathrm{~kg}$, 体温 $36.4^{\circ} \mathrm{C}$, 血王 $166 / 80 \mathrm{mmHg}$, 脈拍 $104 /$ 分，整，意 識清明. 眼䀫結膜に貧血はないが，球結膜に黄疸 を認めた．頸部に異常所見なく，胸部では右胸郭 形成術痕を認めるがラ音なく，心拡大，心雑音も 認めなかつた。腹部は膨隆著明で波動を認め，腹 囲は105.3cmであつた.グル音やや弱く, 腹壁にメ ズサの頭様の静脈怒張を認めた。肝，脾は腹水の ため判然としなかつた。下腿に著明な浮腫を認め た。皮虚は褐色調で胸部, 背部, 前腕に数個のク モ状血管腫を認めた。表在リンパ節腫張なく，神 経学的異常所見は想めなかつた。

一般検査成績(表 1)：ビリルビン尿を認め軽 度の負血，血小板数の減少がみられた。出血時間， 凝固時間は正常であつたが，プロトロンビン時間 の延長拉よびフィブリノーゲン值の低下を認め た，血液生化学では，GOT, GPT, LDH, Alk-Paseの軽度上昇とコリンェステラーゼの著明な低 下，総ビリルビン值扣上び翏質反応の上昇を認め た。血中アンモニアの上昇はなかつた。血清クレ アチニン，尿素空素怙よび電解質は正常内であつ た，血清蛋白は低下し，分画では，アルブミンは $38.2 \%$ と低下. $\gamma$.グロブリンは $44.8 \%$ と増加して いた，血清脂質では，コレステロール(cholesterol : Chol) $90 \mathrm{mg} / \mathrm{dl}$ と低下を示しトリグリセライ

ド (triglyceride : TG)は74mg/dlであつた. ICG 15分值は64\%と著明な排泄低下を認めた，血清反 応ではHBs抗原, 抗体は陰性で， $\alpha$-フェトプロテ インの上昇もなかつた，RA（十）を呈したが， CRP，血清梅毒反応は陰性であつた。

入院後の臨床経過（図 1)：臨床所見および検
表 1. 入院時検查成績

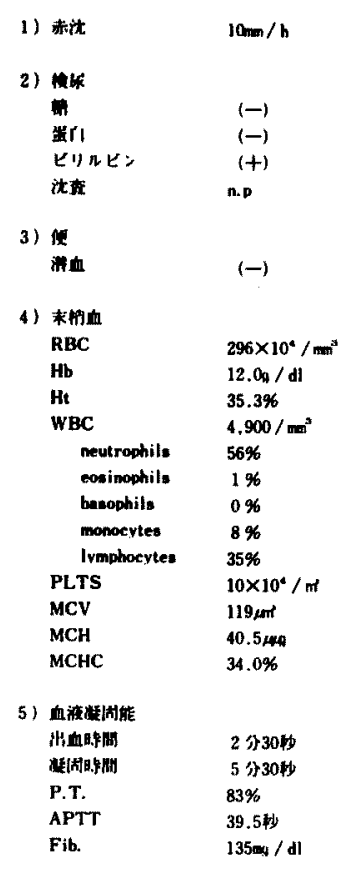

\begin{tabular}{|c|c|c|c|}
\hline \multicolumn{4}{|c|}{ 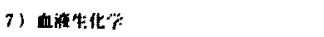 } \\
\hline & GOT & 82 & $\mathbf{U}$ \\
\hline & GPT & 39 & $\mathrm{u}$ \\
\hline & LDH & 360 & $\mathrm{u}$ \\
\hline & $A I^{-1}$ & 122 & $\mathrm{mu} / \mathrm{m}$ \\
\hline & $\mathrm{CH}-\mathrm{F}$ & 0.12 & $\triangle \mathrm{PH}$ \\
\hline & LAP & 37 & U \\
\hline & rGTP & 47 & $\mathrm{mIV}$ \\
\hline & $\mathbf{T}-\mathbf{B} \cdot \mathbf{1}$ & 5.8 & $=0$ \\
\hline & Tehol & 90 & $=/ d$ \\
\hline & $T \mathrm{C}$ & 74 & $\operatorname{mo} / \mathrm{dI}$ \\
\hline & BUN & 6.8 & $=1 d$ \\
\hline & $\mathrm{Cr}$ & 0.8 & $=1 d$ \\
\hline & 血中てンモ二小 & 72 & La / d I \\
\hline & ZTT & 24.2 & U \\
\hline & TTT & 12.3 & $\mathrm{U}$ \\
\hline 8) & dintan & & \\
\hline & Na & 136 & $\mathrm{mEq} / \mathrm{c}$ \\
\hline & $\mathbf{K}$ & 3.2 & $\mathrm{mE} \mathbf{q} / t$ \\
\hline & $\mathrm{Cl}$ & 98 & $\mathrm{mE} / t$ \\
\hline 9) & 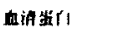 & & \\
\hline & T.P & 5.9 & $a / d$ \\
\hline & Alb & 38.2 & $\%$ \\
\hline & $a c$ & 2.4 & $\%$ \\
\hline & a & 6.3 & $\%$ \\
\hline & $B \mathrm{G}$ & 5.0 & $\%$ \\
\hline & $\gamma \cdot G$ & 44.8 & $\%$ \\
\hline 10) & ICG & 64 & $\%$ \\
\hline 11) & 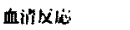 & & \\
\hline & CRP & $(-)$ & \\
\hline & RA & $(+)$ & \\
\hline & TPHA & $(-)$ & \\
\hline & $\hbar \pm x<$ & $(-)$ & \\
\hline & $\mathrm{HB}_{*}-\mathrm{A}_{a}$ & $(-)$ & \\
\hline & AFP & $(-)$ & \\
\hline
\end{tabular}

查成績より黄疸，浮腫，腹水貯留を呈した非代償 期の肝硬变と考えられた。䀒シンチグラムでは， 肝は萎縮性で ${ }^{99 m} \mathrm{~T} c の$ 全体的な集積低下を認める のに対し，脾と骨髄へは強い集積を認めた。明ら かなspace occupying lesionはなかつた。食道・胃 造影では，食道上部まで達する太い静脈瘤を認め た。安静, 減塩高蛋白の食事療法之ともに抗アル ドステロン薬およびフロセミドの静脈内投与を開 始したところ, 入院 5 週目には浮腫, 腹水は消失 し，腹囲は $85 \mathrm{~cm}$ 縮小，体重は $63 \mathrm{~kg}$ と減少した。 その後は利尿薬を経口投与に変点, 経過良好であ つたが，入院 12 週頃より腹水の再咛留を認めたた め, 再度利尿薬の静脈内投与を開始したが腹水の 減少はみられなかつた。14週目の腹水穿刺では黄 白色混濁の乳び様腹水が採取された、ステロイド およびアルブミン製剤の投与も行なつたが腹水詝 留は続いた。 


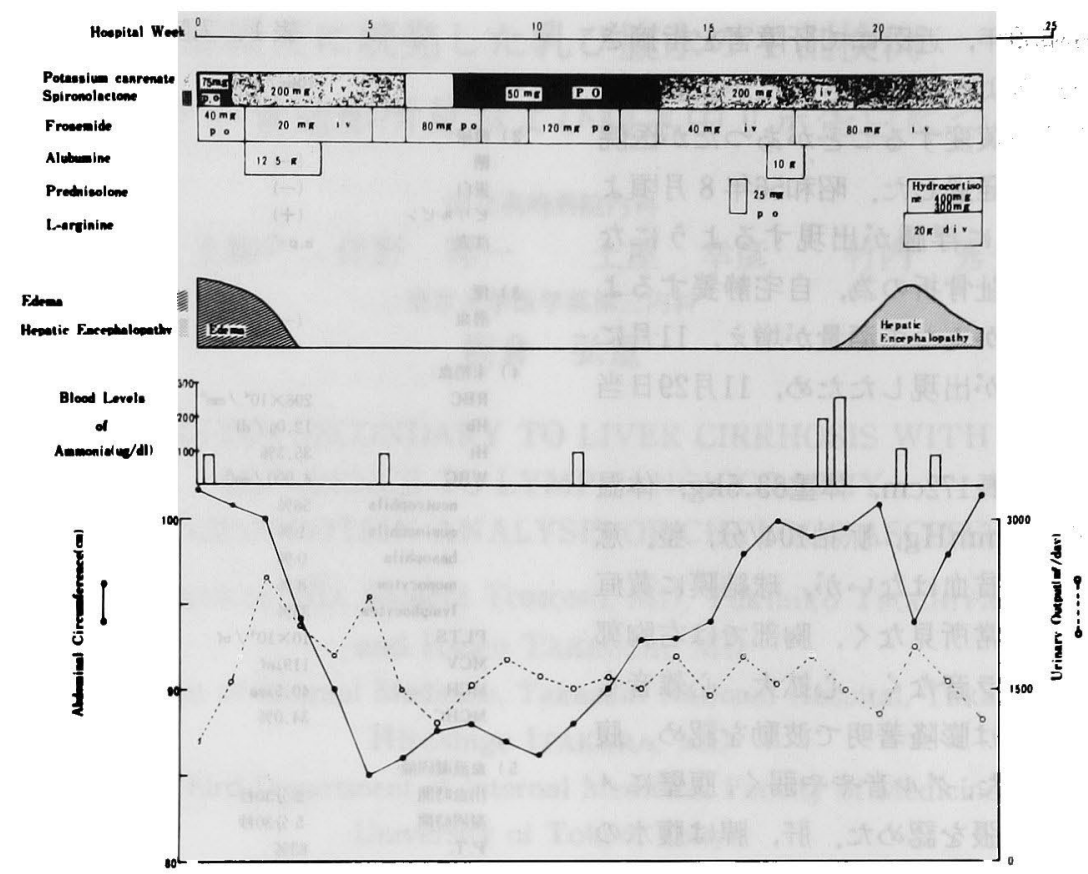

図 1. 臨床経過

表 2. 腹水性状および腹水中の脂質の動き

\begin{tabular}{|c|c|c|c|c|c|c|c|}
\hline \multicolumn{2}{|c|}{ Hospital Week } & 1 & 2 & 14 & \multicolumn{2}{|r|}{20} & \multirow{2}{*}{ 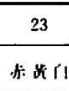 } \\
\hline & 봉 & 藏 & $\ddot{n}$ & 步们 & 赤出门 & 永 & \\
\hline & 比 & $\ldots 016$ & 1.016 & 1.033 & 1.1132 & 1.028 & \\
\hline & {$\left[\mid\left\|_{g} / d\right\|^{\prime}\right)$} & 0.92 & 0.2 & 3.4 & 3.4 & 2.6 & \\
\hline \multirow{3}{*}{$\begin{array}{l}\text { 沈 } \\
\text { 茫 }\end{array}$} & $\begin{array}{lll}\mathbf{R} & \mathbf{B} & \mathbf{C}\end{array}$ & $14 \sim 18 / 1 \mathrm{~F}$ & & $3 \quad z^{2}$ & 每 & 算 & \\
\hline & II $B$ & $8-10 / 1 \mathrm{~F}$ & & 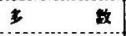 & $15 \sim 20 / 1 \mathrm{~F}$ & $20-22 /$ IF & \\
\hline & 枋 & $6-8 / 1 \mathrm{~F}$ & & $1 / 5 \sim 7 \mathrm{~F}$ & $1 \sim 2 / 1 \mathrm{~F}$ & $1 / 2-3 F$ & \\
\hline & 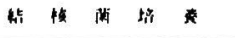 & $1-1$ & $1-1$ & $(-)$ & $(-1$ & & \\
\hline & 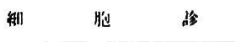 & Class I & Class I & Class II & Class [ & Class I & \\
\hline & T $\quad$ G $(\mathrm{mo} / \mathrm{dl})$ & 29 & 68 & 129 & 248 & 256 & 226 \\
\hline & C h I (mo/dl) & 16 & 16 & 53 & 58 & 48 & 37 \\
\hline & $\mathrm{TG} / \mathrm{C}$ hol ratio & 1.8 & 4.3 & $2 . *$ & 4.3 & 5.3 & 6.1 \\
\hline & 校 所 $(\mathrm{m} / \mathrm{d} / \mathrm{l})$ & & & & & 390 & \\
\hline & 血 in $T \in(m / d)$ & 100 & 74 & 67 & 70 & 74 & 75 \\
\hline & 血 if $\mathrm{T}-\mathrm{Chol}(\mathrm{mg} / \mathrm{dl})$ & 116 & 107 & 134 & 132 & 136 & 133 \\
\hline & 血 领 $(1 \quad(R / d)$ & 5.9 & 5.8 & $\ldots$ & 0.0 & 6.0 & 5.9 \\
\hline
\end{tabular}

腹水性状の変化：表 2 は入院経過中の腹水性 状と腹水中の脂質の動きを示す. 入院 1 ～ 2 週で は, 比重, 蛋白濃度とも低く, 漏出液の性状を示
していた. しかし, 再貯留後の14週以後では高比 重, 高蛋白となり, また, 腹水中脂質は著増して, 特にTGは血清値よりも高く, TG/Chol比は高値 


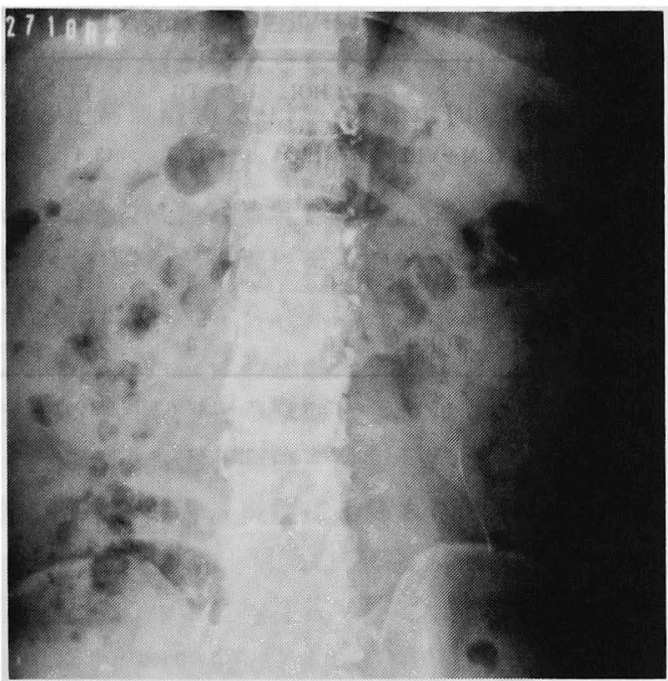

正面像

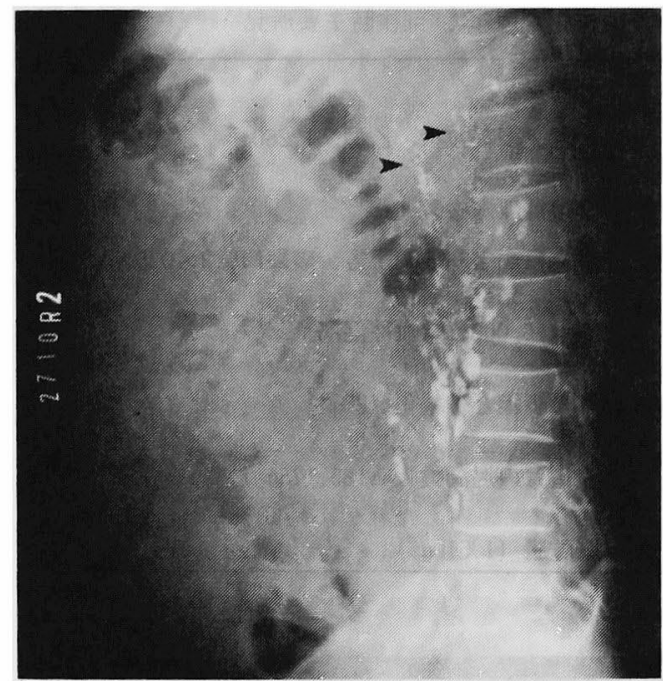

側面像

図 2.リンパ管造影像(24時間後). 大動静脈管リンパ節は, 第 2 腰椎で造影不良, 第 1 腰椎以上では造影されていない. 側面像では, 逆行性に異常リンパ路が造影されて いる (矢印).

を示した。

リンパ管造影所見(図 2)：大動静脈間リンパ 節は，第 2 腰椎の高さで急に造影不良となり，第 1 腰椎以上では造影されず, 側面像では逆行性に 異常リンパ路が造影されて扣り，乳び槽近くでの リンパ路の閉塞が示唆された。ただし，胸管は造 影されなかつたが，左鎖骨下静脈への開口部は造 影されており, 閉塞は不完全なものと考えられた。 腰部拉よび腹腔内リンパ節の数, 形態に異常は認 められなかつたが大腿部リンパ管のうつ滞所見が 認められた。

腹部CTおよび肝シンチグラム： 腹部CT（図 3) では肝の萎縮と軽度の脾腫および著明な腹水 貯留を認めたが，大動脈傍リンパ節の拡大や胸管 の異常は認められず，またmass lesionも認められ なかつた。肝シンチグラムは入院時と同様で space occupying lesionはみられなかつた。

患者はその後, 肝性脳症が出現し, 食道静脈瘤 破裂によると思われる大量吐血のため，入院23週 で他界した。

剖検所見（表 3）：僅かに乳様混濁を示す赤褐 色の血性腹水が約 10000 cc貯留していた。肝は萎縮

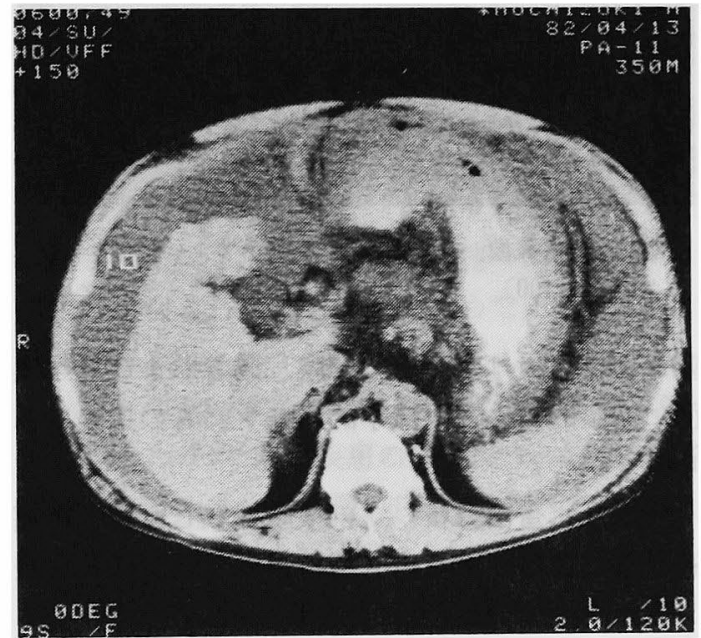

図 3. 腹部CT像. 肝の萎縮と軽度の脾腫および多量の 腹水を認める、全スライスを通じて大動脈傍リンバ節 の拡大や胸管の異常はなく mass lesionもなかつた。

性で表面は黄色微細顆粒状を呈し, 組織像(図 4) は乙型肝硬変であつた。 Disse腔および肝内リンパ 路の拡張は認められなかつた。食道には静脈瘤を 認め, 胃入口部より $6 \mathrm{~cm}$ 上方に径 $0.2 \times 0.5 \mathrm{~cm}$ の破 裂ロが認められた，胸管および乳び槽の破壊，閉 
表 3 . 剖検時主要所見

\section{1、肝硬変}

黄色微細顆粒状、乙型、 $1,260 \mathrm{~g}$

\section{2、食道静脤㾔破裂}

胃入口部より $6 \mathrm{~cm}$ 上方、破裂口 $0.2 \times 0.5 \mathrm{~cm}$

3、胶水 $10,000 \mathrm{cc}$ (血性混濁)

4、䏼の娄繀と線維化（80g）

5、左右肾の混濁腫脤（185、175g）

6 、脑腫脹 $(1,510 \mathrm{~g})$

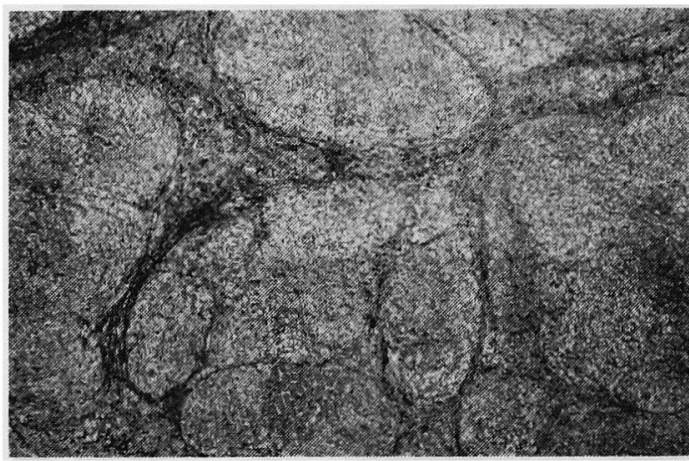

図 4. 肝組織像. 乙型肝硬変像を示寸（マロリー染 色, $\times 100$ )

塞および扗大はなく，腸間膜，腸管および胃浆膜 面に肉眼的括よび組織学的にリンパ管の拡張はみ られなかつた。

腹水リポ蛋白分析： 剖検時採取した腹水の超 遠心法によるリポ蛋白分析結果と各脂質成分を表 4 亿示す.リポ蛋白では比重1.006以下のカイロ クロン（chylomicron:CM）と超低比重リポ蛋白 (very low density lipoprotein: VLDL) の分画 がほとんどを占め，他の低比重リポ蛋白（low density lipoprotein : LDL), 高比重リポ蛋白(high density lipoprotein : HDL) 分画はほんの少量し か認められなかつた。 また脂質成分ではTGが圧 倒的に多く，血清値の約 3 倍であつた。さらに $\mathrm{CM}+\mathrm{VLDL}$ 分画を分離採取し，これに polyacrylamide gel electrophoresis (PAGE) を用い
表 4. 腹水リポ蛋白分析 (mg/dl)

\begin{tabular}{rlccc}
\hline & CHOL. & TG & PL & Protern \\
$\mathrm{J}\langle 1.006$ (CM+VLDL) & 34.9 & 217.7 & 43.4 & - \\
$1.006<\mathrm{d}(1.063$ (LDL) & 8.4 & 26.5 & 8.5 & 7.7 \\
$1.063<\mathrm{d}(1.125$ (HDL $)$ & 0 & 3.4 & 4.1 & trace \\
$1.125<\mathrm{d}(1.21$ (HDL3) & 0 & 0 & 2.9 & trace \\
\hline & 43.3 & 247.6 & 58.9 &
\end{tabular}

(a)

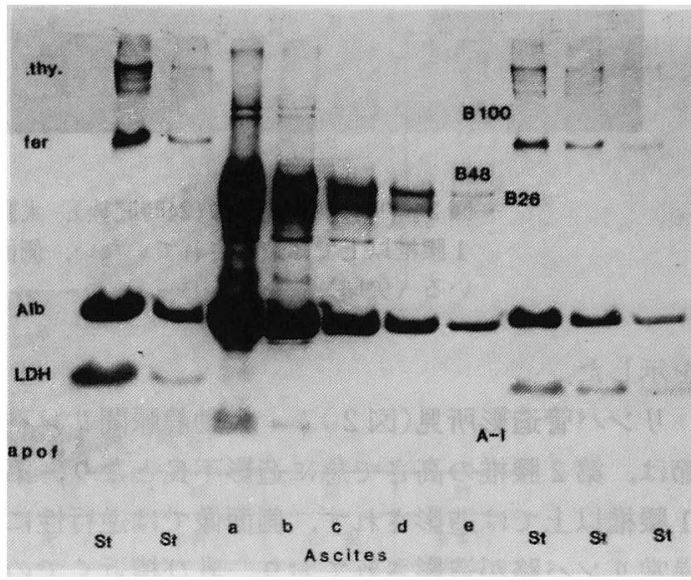

（b）腹水中アポ $\mathrm{A}$ 定量（SRID法）

$$
\begin{array}{lc}
\text { アポAI } & 10.6 \mathrm{mg} / \mathrm{dl} \\
\text { アポAII } & 1.3 \mathrm{mg} / \mathrm{dl} \\
\text { アポAI/アポAII比 } 8.2
\end{array}
$$

図 5.（a）腹水中のCM+VLDL分画 $(d<1.006)$ の PAGEを用いたアポリポ蛋白分析。アポBでは腸管由 来のアポ $\mathrm{B}_{48}$ の他に肝由来のアポ $\mathrm{B}_{100}$, アポ $\mathrm{B}_{26}$ が認め られる.フポAではアポAIを認めるが, アポAIIのバン ドは,はつきりしない。

thy：サイログロブリン, fer：フーリチン, Alb：フ ルブミン, LDH, apof：アポフェリチン, St：コント ロール血清, a, b, c, d, e：検体の希釈系列

(b) アポAI/フポAII比の増加を認める.

たアポリポ蛋白分析(図 5 )ではアポAとアポBを 認めたが，アポBでは腸管由来と考えられるアポ $\mathrm{B}_{48}$ とともに肝由来と考号れるアポ $\mathrm{B}_{100}$, 丁ポ $\mathrm{B}_{26}$ も認められた。 またアポAでは, アポAIのバン ドを認めるがアポAIIは明瞭でなく, single radial imunodiffusion (SRID) 法を用いての腹水中のア 
ポA定量では, アポAI $10.6 \mathrm{mg} / \mathrm{dl}$, アポAII 1.3 $\mathrm{mg} / \mathrm{dl}$ とアポAIが著しく多く、アポAI/アポAII比 は8.2と正常血清値よりはるかに増加していた。

\section{III. 考 案}

一般に成人における乳び腹水の成因としては， 腸管リンパ路から胸管に至る経路のいずれかにリ ソパ路の閉塞が起こり，リンパ管内压の上昇をき たした場合，およびリンパ路が破壊された場合が 考兄られている，その原因としては，外傷を除け ば,リンパ腫および莘癌, 卵巣腫瘍などの腹腔内 腫瘍によるものと，炎症によるるのが多いとされ ている(1) 4). その他, 門脈血栓症, 萊炎に続発した 門脈括よび脾静脈血栓症 ${ }^{2)}$, 蛋白丧失性胃腸症, 絞 拒性イレウス ${ }^{3)}$, 後腹膜リンパ節摘出術や門脈圧 上昇に対する静脈シャント術等の腹部手術後(5) 等 が報告されている。

肝硬変でも乳び腹水を生じることがあるがまれ であり ${ }^{122677)}$, 本邦における報告例は少ない(38899).腫 瘍や资症によるものではリンパ路の閉塞ないし破 壊が証明されているのに対し，肝硬変例では明ら かな閉塞所見はみられていない377. 一般に肝硬变 における腹水発生の主因は，門脈圧上昇および血 䍝膠質浸透王低下による腹腔内蔵器毛細血管より の血浆成分の漏出と, 肝表面よりのリンパ漏出と 考えられている(10). 肝硬変では, 肝小葉構築の变化 に基づく，類洞ないし類洞後狭窄により血浆成分 のリンパ路流入をひき起こし訮リンパ過剩生成を きたす。このように過剩生成された肝リンパは， 一部肝表面より腹腔内へ漏出するとともに, 正常 の $3 \sim 6$ 倍の胸管流量の増加とリンパ管内圧の上 昇をきたすとされている ${ }^{11}$ ，従つて肝硬变におけ る乳び腹水の成因としては，リンパ管内圧の上昇 による腸管リンパ路の破裂ないし透過性え進によ る腸管リンパの腹腔内への漏れと考えるのが妥当 と思われる。

ここで問題となるのは，肝硬変における乳び腹 水生成は，リンパ管内王の一層の上昇といら腹水 生成機序の延長線上にあるものなのか，他に別な 要因を必要とするのかである，Malageladaら7) は，肝硬変で乳び腹水を呈した 3 例と非乳び腹水
例 8 例に放射性物質でラベルした中および長鎖脂 肪酸を投与し，その血中および腹水中での動態を 検討し, 非乳び腹水例では径の小さい, 少量のCM が腸管リンパより腹腔内へ漏れるのに対し，乳び 腹水例では漏れだすCMの数と大きさが増大し乳 びを呈してくるとしている，本例の腹水中の脂質 の動きをみると，乳びを呈さない時期であ徐々に TGは增加している。したがつて，本例に㧍ける乳 び腹水の発生は, Malageladaらの症例と同様な機 序によるものと考兄られる。すなわち，肝硬変に よる肝小葉構築の变化 $\rightarrow$ 類洞狭窄 $\rightarrow$ 血浆成分のリ

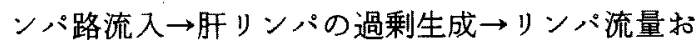
よびリンパ管内圧の上昇の経過をとり，これによ り最初は少量の小さいCMの漏出が，より一層の リンパ管内圧の上昇を来たすに至つて，より大き な大量のCMが腹腔内へ流れ乳びを呈するように なつたと考えたい，リンパ系の形成不全等の要因 は必須ではないと思われる。なお本例において著 明なリンパ管内圧の上昇を示すDisse空の拻大や 腸管リンハ路の拡大はみられていないが,これは, （1）死後変化によりリンパ路が虚脱状態になつて いる可能性があること，（2）リンパ管造影より示 唆されるように豊富な側副りンパ路の形成が早期 になされたこと，(3）乳びの腹腔内への漏れによ り減圧がなされたこと，等のためであるとすれば 説明できよう。

近年,リンパ管造影が乳び腹水例にも施行され るようになり ${ }^{12)}$, 基礎疾患の推測, リンパ路の閉塞 部位の診断, リンパの腹腔内への漏れの確認が可 能となつたが13144，肝硬変による乳び腹水例での 施行は少ない、78). 本例では, L1〜L2で造影不良と なり，乳び槽近くでの不完全閉塞を思わせる所見 と豊富な異常側副リンパ路の形成および大腿部り ンパ管のらつ滞所見がみられたが，剖検ではリン パ路の閉塞を思わせる所見はなかつた。

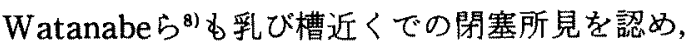
リンパ管の襄胞状扗大とあわせてリンパ管形成不 全の一つの根拠としているが，剖検時には，やは り閉塞所見を認めていない，著者らはこのリンパ 管造影と剖検所見との解離を次のように考えた 
いすななわ，肝硬変では先に述ぺたようにリン パの過剰生成が起きて括り，肝リンパの乳び槽へ の流入は増大している。このため，下肢からのリ ンパは乳び槽への流入を障害されらつ滞を起こす と考えられる。従つて，足背リンパ管から注入さ れた造影剤は乳び槽以下でらつ滞しこれが本症 例でみられた大眼リンパ管のらつ滞所見として表 われ，また，閉塞による乳び槽への注入障害があ るよらにみえたと考光た。本症例にみられた“偽 性閉塞”とも言らべきリンパ管造影所見が，肝硬 変による乳び腹水例の特徵なのか否か，今後の検 討を待ちたい

胸管リンパの脂質組成では，TGが他のCholや リン脂質よりも高く，その濃度は食事により変動 するとされている15). Malageladaらは, 肝硬変で 乳び腹水を呈した症例の腹水中の脂質を分析し， TGの比率が高く，その組成が胸管リンパの組成 とほぼ一致することを確かめ，これを乳び腹水の 診断基準としている，また，Watanabeらは，腹水 中の TG/Chol比をとり，この值の上昇（肝硬変で 乳び腹水例 1.94 , 非乳び腹水例0.89）をより簡便 な診断基準としている，本例に拈いても，腹水中 のTGは他の脂質よりも王倒的に多く，TG/Chol 比は2.4〜6.1と上昇しており乳びであるといえ る。近年，腹水のリポ蛋白分析が行なわれるよう になり, 超低比重りポ蛋白以下のリポ蛋白が増加 している場合，腸管リンパ由来，すなわち乳びと 考えられるよらになつた ${ }^{716)}$. 本例においては，比 重1.006以下（CM+LVDL）のリポ蛋白分画が压 倒的に多く，この面からも乳び腹水であることが 確かめられた。高た，HDL-Cholは注とんど認めら れず，腹水中脂質における肝りンパの関与は少な いと考えられた。

釈び腹水のアポ蛋白分析を行なつた報告例は少 なく ${ }^{16)}$, 肝硬変例での分析は著者らの知るかぎり

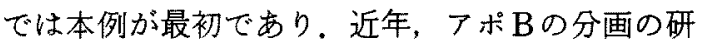
究がなされ，それぞれの生成臓器が判別されるよ らになつた ${ }^{1718)}$. 本例に颃いて興味深いことは, 腸 管由来のアポ $\mathrm{B}_{48}$ が見られるのは乳び腹水として 当然と思われるが，肝由来と考えられるアポ $\mathrm{B}_{100}$,
アポB $\mathrm{B}_{26}$ がみられたことである、このことは，非乳 び腹水中に存する少量の脂質には肝リンパ漏出に 上るものが含まれ，これに腸管リンパの混入が加 わると乳びを呈してくることを示唆するものと思 われる，今後，腹水中のアポB分画の検索がより 多く行なわれるようになれば，肝硬変に括ける腹 水生成において肝リンパの関与の程度を推察でき るかも知れない，最近，板倉らは，各種疾患のア ポAの血中濃度を測定し，肝硬変ではアポ $\mathrm{A}$ の低 下を認めるとともにアポAI/アポAII比の増加

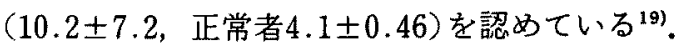
本例では腹水のアポAI/AII比は 8.2 と増加してい たが，このことは肝硬変に执ける血中アポ蛋白異 常を反映しているものと考觉られた。

\section{IV，まとめ}

50才，男性，肝硬変に乳び腹水を続発し，食道 静脈瘤破裂により死亡した症例を報告した，肝硬 変に括ける乳び腹水は，肝小葉構築の変化 $\rightarrow$ 類洞 ないし類洞後狭窄 $\rightarrow$ 肝リンパ過鄱生成 $\rightarrow$ 腸管リン パ内圧上昇といら一連の機序により生じるるのと 考えられる. 本例のリンパ管造影では乳び槽の閉 塞を示す所見がみられたが，これは，肝リンパの 乳び槽への流入の増大のための見かけ上の閉塞 (偽性閉塞)の可能性がある。なお，乳び腹水のリ ポ蛋白分析が，その診断，起源の解明に有用であ ることを指摘した。

謝辞 群馬大学第二内科 村田和彦教授の御校閲に深謝 します。

\section{文献}

1) Nix JT, et al: Chylothorax and chylous ascites; a study of 302 selected cases. A J Gastroenterol $28: 40,1957$.

2) Kelly ML, et al: Chylous ascites; an analysis of its eliology. Gastroenterology $39: 161,1960$.

3) Tsuchiya M, et al: Chylous ascites formation and a review of 84 cases. Angiology $24: 576$, 1973.

4) Patel RM and Purow E: Chylous ascites and chylothorax; presenting manifestation of pan. creatic carcinoma. Ann Surg 156:668, 1962.

5) Schulman A, et al: Lymphography in postvagotomy chylous ascites. Brit J Radiol 54 : $915,1981$. 
6) Caroli J, et al: Ascite chyleuse du cirrhotique. Rev Med Chir Mal Foie 44: 99, 1969.

7) Malagelada JR, et al: Origin of fat in chylous ascites of patients with liver cirrhosis. Gastroenterology $67: 878,1974$.

8) Watanabe $M$, et al: A case of liver cirrhosis with chylous ascites and multiple cystic dilatation of the abdominal lymphatic system. Hepato-Gastroenterology $27: 394,1980$.

9）藤本隆史，他：乳び腹水を伴つた肝硬变の1例。 日消会誌 $79: 1054,1982$ (会).

10) Libowitz HR: Pathogenesis of ascites in cirrhosis of the liver. NY State J Med 69: 1895, 1969.

11) Dumont AE, Mulholland JH : Alterations in thoracic duct lymph flow in hepatic cirrhosis. Ann Surg 156: 668, 1962.

12) Choen $R$, et al: Lymphangiography in a patients with chylous ascites. Radiol $81: 219$, 1963.

13) Carven $\mathrm{CE}$, et al : Congenital chylous ascites; lymphangiographic demonstration of obstruc. tion of the cisterna chyli and chylous reflex into the peritoneal space and small intestine. J Pediat $70: 340,1967$.

14) Camiel MR, et al: Chylous ascites with lymphographic demonstration of lymph lea. kage into the peritoneal cavity. Gastroenterol $47: 188,1964$.

15) Bartlett RH, et al: Lipid studies on human lymph and chyle. JAMA $187:$ 126, 1964.

16) Malmendier CL, et al: Metabolism of lipoproteins in human chylous ascites; kinetic and static studies of lipids and apoproteins. Clin Chim Acta $77: 227,1977$.

17) Kane JP, et al: Heterogeneity of apolipoprotein $\mathrm{B}$; isolation of a new species from human chylomicrons. Biochemistry $77: 2465$, 1980.

18) Aburatani $\mathrm{H}$, et al: Analysis of apolipoproteins $\mathrm{B} 100$ and $\mathrm{B} 48$ by sodium dodecyl sulfate polyacrylamide gradient gel electrophoresis. J Biochem (in press)

19）板倉弘重，他：フポAI, アポAIIとHDL亜分画に 関する臨床的検討。動脈硬化 $11: 443,1983$. 